\title{
PENGENALAN MACAM-MACAM BUAH DARI \\ HURUF HANGEUL (BAHASA KOREA) MENGGUNAKAN \\ TEKNOLOGI AUGMENTED REALITY BERBASIS ANDROID
}

\author{
Harya Gusdevi $^{1}$, Frencius ${ }^{2}$, Luthfiana Nisrina Khaerunisa ${ }^{3}$ \\ Prodi Informatika \\ Sekolah Tinggi Teknologi Bandung \\ Email: deviharya@gmail.com ${ }^{1}$, frenciusleonardus@yahoo.com, \\ nisrinaluthfiana@gmail.com
}

\begin{abstract}
Abstrak: Saat ini semakin banyak orang menaruh minat untuk mempelajari bahasa asing selain Bahasa Inggris, salah satunya Bahasa Korea. Dengan berkembangnya teknologi informasi saat ini, sarana pengenalan tersebut dapat dilakukan menggunakan perangkat keras seperti komputer, laptop maupun smartphone. Perkembangan teknologi Augmented Reality pada smartphone akan mempermudah anak dalam mengenal macam-macam buah dalam bahasa asing yang salah satunya yaitu huruf hangeul (Bahasa Korea). Metode yang dilakukan dalam pembuatan aplikasi ini adalah studi literatur, observasi, wawancara dan kuesioner. Aplikasi disusun dengan prosedur yang mencakup identifikasi masalah, analisis kebutuhan sistem, merancang konsep, merancang isi, merancang naskah, memproduksi sistem, pengetesan sistem dengan alpha dan beta test, penggunaan sistem dan tahap akhir yaitu memelihara sistem. Hasil penelitian aplikasi ini, khususnya cara penulisan dan cara pengucapan bagi siswa kursus Bahasa Korea kelas dasar. Aplikasi telah diuji coba menggunakan alpha dan beta test. Berdasarkan hasil uji coba tersebut dapat disimpulkan bahwa aplikasi ini dapat membantu proses pembelajaran secara mandiri pada siswa dan dapat digunakan sebagai alat bantu guru yang dapat menunjang pembelajaran Bahasa Korea di kelas.
\end{abstract}

Kata Kunci: Huruf Hangeul, Buah, Android, Augmented Reality.

\section{Pendahuluan}

Bahasa merupakan alat komunikasi yang penting bagi manusia. Di era globalisasi saat ini, bahasa menjadi kebutuhan utama untuk melakukan berbagai aktivitas baik saat bekerja maupun bersosialisasi di lingkungan masyarakat. Banyak orang menaruh minat untuk mempelajari bahasa asing selain bahasa Inggris, salah satunya yaitu Bahasa Korea.Hangeul adalah nama resmi dari Bahasa Korea yang dipakai oleh Bangsa Korea setelah diciptakan oleh Raja Agung Sejong, Dinasti Chosun pada tahun 1443. Jumlah huruf Hangeul adalah 24 yang terdiri atas 10 huruf vokal dan 14 huruf konsonan [1].

Sejauh ini, respon masyarakat untuk mempelajari Bahasa Korea mulai tinggi. Sejumlah cara dapat dilakukan untuk mempelajari Bahasa Korea seperti mengikuti kursus, 
mendengarkan lagu, menonton film Korea serta melalui internet [1]. Saat melakukan penelitian di salah satu lembaga kursus bahasa asing termasuk Bahasa Korea, beberapa kesulitan terlihat ketika guru memerintahkan siswa/i untuk menulis salah satu kata dalam huruf Hangeul, salah satunya saat diminta menyebutkan nama-nama buah, karena kebanyakan siswa/i yang mengikuti kelas tersebut adalah orang awam atau belum pernah sama sekali mempelajari huruf Hangeul, sehingga saat menulis mereka masih terus membuka modul untuk melihat huruf Hangeul yang tepat untuk membentuk kata yang diberikan. Kesulitan itu juga terlihat saat membaca suatu kata dalam Bahasa Korea, kebanyakan mereka masih sulit dalam melafalkan huruf dengan benar sehingga kata yang mereka sebutkan menjadi salah pengucapannya.

Pada saat mempelajari nama-nama buah dalam huruf Hangeul, sebenarnya secara tidak langsung kita telah mempelajari dasar-dasar dari huruf Hangeul, karena pada nama-nama buah dalam huruf Hangeul tersebut sudah terdapat semua huruf-huruf dasar dari Hangeul, dengan nama-nama buah dalam bentuk bahasa Indonesia dengan Korea yang cara membacanya tidak jauh berbeda, memudahkan dalam cara mengingat nama-nama buah dan secara tidak langsung mengingat huruf Hangeul juga karena dalam nama buah tersebut terdiri dari huruf-huruf dasar Hangeul yang paling mudah.

Untuk menunjang proses pembelajaran tersebut, telah digunakan kamus cetak dan elektronik sebagai alat bantu, sejauh ini terdapat beberapa kendala yang dihadapi dalam pengunaan kamus cetak dan elektronik, salah satunya membutuhkan waktu yang lama untuk mencari kata yang diinginkan serta kurang menariknya tampilan. Salah satu solusi untuk mengatasi permasalahan tersebut adalah dengan menggunakan aplikasi pengenalan macam-macam buah dari huruf Hangeul (Bahasa Korea) menggunakan teknologi Augmented Reality berbasis Android.Pengguna dapat memasang aplikasi pada Android yang dimiliki, dan dapat dengan mudah mencari nama-nama buah dalam Bahasa Korea yang ingin diketahui secara offline.

Aplikasi ini dibuat menggunakan teknologi Augmented Reality. Augmented Reality adalah teknologi yang memungkinkan orang untuk memvisualisasikan dunia maya sebagai bagian dari dunia nyata yang ada di sekitar secara efektif sehingga membuat dunia nyata seakan-akan dapat terhubung dengan dunia maya dan dapat terjadi suatu interaksi.

\section{Tinjauan Pustaka}

Hangeul adalah nama resmi dari Bahasa Korea yang dipakai oleh Bangsa Korea setelah diciptakan oleh Raja Agung Sejong, Dinasti Chosun pada tahun 1443. Jumlah huruf Hangeul adalah 24 yang terdiri atas 10 huruf vokal dan 14 huruf konsonan [1].Aturan penulisan dalam Hangeulsama seperti bahasa lainnya, bisa ditulis dengan penulisan horizontal yaitu penulisan dimulai dari arah kiri ke kanan, sedangkan penulisan secara vertikal dengan penulisan yang dimulai dari arah atas ke bawah.Berikut pembagian hurufhuruf Hangeul[3]: 
a. Huruf Vokal

Huruf Korea vokal Dasar terdiri dari 10 huruf. Berikut huruf-huruf Korea vokal dasar beserta cara membacanya seperti pada Tabel 1 .

Tabel 1. Huruf Vokal(Sumber : [3])

\begin{tabular}{|c|c|c|}
\hline No & Huruf & Bunyi \\
\hline 1 & 아 & $\mathrm{A}$ \\
\hline 2 & 야 & Ya \\
\hline 3 & 어 & eo/o \\
\hline 4 & 여 & $\mathrm{O}$ \\
\hline 5 & 오 & Yo \\
\hline 6 & 요 & $\mathrm{U}$ \\
\hline 7 & 우 & $\mathrm{Yu}$ \\
\hline 8 & 유 & $\mathrm{eu} / \mathrm{u}$ \\
\hline 9 & 으 & $\mathrm{I}$ \\
\hline 10 & 이 & \\
\hline
\end{tabular}

\section{b. Huruf Konsonan}

Huruf Korea konsonan dasar ini terdiri dari 14 huruf. Berikut adalah huruf Korea konsonan dasar beserta cara membacanya seperti pada Tabel 2.2 .

Tabel 2. Huruf Konsonan (Sumber : [3])

\begin{tabular}{|c|c|c|c|c|c|}
\hline No & Huruf & Nama & Bunyi Awal & Bunyi Tengah & Bunyi Akhir \\
\hline 1 & $\neg$ & Kiyeok & $\mathrm{k} / \mathrm{g}$ & $\mathrm{g}$ & $\mathrm{K}$ \\
\hline 2 & \llcorner & Nieun & $\mathrm{N}$ & $\mathrm{n}$ & $\mathrm{N}$ \\
\hline 3 & $\sqsubset$ & Tigeut & $\mathrm{t} / \mathrm{d}$ & $\mathrm{d}$ & $\mathrm{T}$ \\
\hline 4 & $己$ & Rieul & $\mathrm{r} / \mathrm{l}$ & $\mathrm{r} / \mathrm{l}$ & $\mathrm{L}$ \\
\hline 5 & $\square$ & Mieum & $\mathrm{M}$ & $\mathrm{m}$ & $\mathrm{M}$ \\
\hline 6 & $\bullet$ & Pieup & $\mathrm{p} / \mathrm{b}$ & $\mathrm{b}$ & $\mathrm{P}$ \\
\hline 7 & $\curlywedge$ & Siot & $\mathrm{S}$ & $\mathrm{s}$ & $\mathrm{T}$ \\
\hline 8 & $\circ$ & Ieung & - & - & $\mathrm{Ng}$ \\
\hline 9 & ス & Chieut & $\mathrm{Ch}$ & $\mathrm{j}$ & $\mathrm{T}$ \\
\hline 10 & テ & ch'ieut & $\mathrm{Ch}$ & $\mathrm{ch}$ & $\mathrm{T}$ \\
\hline 11 & $\exists$ & khieuk & $\mathrm{Kh}$ & $\mathrm{kh}$ & $\mathrm{K}$ \\
\hline 12 & $\in$ & thieut & $\mathrm{Th}$ & th & $\mathrm{T}$ \\
\hline
\end{tabular}




\begin{tabular}{|c|c|c|c|c|c|}
\hline 13 & 프 & phieup & $\mathrm{Ph}$ & $\mathrm{ph}$ & $\mathrm{P}$ \\
\hline 14 & $\bar{\sigma}$ & hieut & $\mathrm{H}$ & $\mathrm{h}$ & $\mathrm{T}$ \\
\hline
\end{tabular}

\section{c. Huruf Vokal Gabungan}

Berikut huruf Korea vokal rangkap yang terdiri dari 11 huruf gabungan dari vokal dasar seperti pada Tabel 3.

Tabel 3. Vokal Gabungan (Sumber : [3])

\begin{tabular}{|c|c|c|c|}
\hline No & Huruf & Bunyi & Proses \\
\hline 1 & 애 & ae/e & 아 + 이 \\
\hline 2 & 애 & yae/ye & 야 + 이 \\
\hline 3 & 에 & $\mathrm{E}$ & 어 + 이 \\
\hline 4 & 예 & Ye + 이 \\
\hline 5 & 외 & Oe & 오 + 이 \\
\hline 6 & 와 & wae/we & 오 +아 \\
\hline 7 & 왜 & Wo + 애 \\
\hline 8 & 워 & We & 우 +어 \\
\hline 9 & 웨 & Wi & 우 에 \\
\hline 10 & 위 & eui/ui & 우 + 이 \\
\hline 11 & 의 & 이 \\
\hline
\end{tabular}

\section{d. Huruf Konsonan Gabungan}

Huruf Korea konsonan rangkap adalah perkembangan dari huruf Korea konsonan dasar.Berikut adalah huruf Korea konsonan rangkap yang terdiri dari 5 hurufseperti pada Tabel 2.4.

Tabel 4. Konsonan Gabungan (Sumber : [3])

\begin{tabular}{|c|c|c|c|c|}
\hline No & Huruf & Bunyi Awal & Bunyi Tengah & Bunyi Akhir \\
\hline 1 & $ר$ & $\mathrm{Kk}$ & $\mathrm{kk}$ & $\mathrm{k}$ \\
\hline 2 & & $\mathrm{Tt}$ & $\mathrm{tt}$ & - \\
\hline 3 & $\forall$ & $\mathrm{Pp}$ & $\mathrm{pp}$ & - \\
\hline 4 & $\mu$ & $\mathrm{Ss}$ & $\mathrm{ss}$ & $\mathrm{t}$ \\
\hline 5 & $\pi$ & $\mathrm{Cc}$ & $\mathrm{cc}$ & - \\
\hline
\end{tabular}

Augmented Reality (AR) adalah konsep pelapisan konten visual (seperti grafik) di atas pemandangan dunia nyata seperti yang terlihat melalui sebuah kamera. $A R$ mentransformasi perangkat mobile ke dalam sesuatu yang digambarkan sebagai suatu cermin ajaib sehingga akan terjadi interaksi dengan dunia nyata.Ada tiga karakteristik yang menyatukan suatu teknologi menerapkan konsep $A R$ [4] yaitu. 
1) Mampu mengkombinasikan dunia nyata dan dunia maya,

2) Mampu memberikan informasi secara interaktif dan real-time,

3) Mampu menampilkan dalam bentuk 3D (tiga dimensi).

Android merupakan sistem operasi yang berisi middleware serta aplikasi-aplikasi dasar.Basis sistem operasi Android yaitu kernel Linux 2.6 yang telah diperbaharui untuk mobile device [5]. Sedangkan pendapat lain mengatakan bahwa Android adalah sebuah sistem operasi untuk perangkat mobile berbasis linux yang mencakup sistem operasi, middleware dan aplikasi. Android menyediakan sistem operasi yang terbuka bagi para pengembang untuk menciptakan aplikasi [6].Pengembangkan aplikasi Android menggunakan bahasa pemrograman Java. Yang mana konsep-konsep pemrograman Java berhubungan dengan Pemrograman Berbasis Objek (OOP)). Selain itu pula dalam pengembangan aplikasi Android membutuhkan Software Development Kit (SDK) yang disediakan Android, SDK ini memberi jalan bagi programmer untuk mengakses application programming interface (API) pada Android [7].

Unity merupakan salah satu game engineyang multiplatform (dapat dijalankan di semua sistem operasi).Selain itu, Unity juga mendukung berbagai macam bahasa pemrograman seperti Javascript, C\#, dan Boo [8]. Unity Game Engine adalah software yang digunakan untuk membuat video game berbasis dua atau tiga dimensi dan dapat digunakan secara gratis. Selain untuk membuat game, Unity juga dapat digunakan untuk membuat konten yang interaktif lainnya, seperti visual arsitektur dan real-time $3 D$ animasi. Selain sebagai game engine, unity juga dapat digunakan sebagai sebuah editor bagi game yang sudah ada [9]. Unity dibuat dengan menggunakan bahasa pemrograman $\mathrm{C}++$. Selain itu, Unity juga mendukung bahasa program lain seperti JavaScript, C\#, dan Boo. Adapun kelebihan dari Unity, yaitu dapat dioperasikan pada platform Windows dan Mac Os. Selain itu, Unity juga dapat menghasilkan game untuk Linux, Wii, iPad, iPhone, Android, dan juga browser [10].

Bahasa pemrograman $C \#$ (dibaca $C$ sharp) adalah bahasa pemrogramantingkat tinggi (high-level language) yang mirip dengan Java dan $C++$, dan padabeberapa bagian mirip dengan Delphi, VB.Net, dan C. Semua program C\#adalahberbasis objek (object oriented)[11].

Notasi $U M L$ merupakan sekumpulan bentuk khusus untuk menggambarkan berbagai diagram piranti lunak. Setiap bentuk memiliki makna tertentu, dan UMLsyntax mendefinisikan bagaimana bentuk-bentuk tersebut dapat dikombinasikan. Notasi $U M L$ terutama diturunkan dari 3 notasi yang telah ada sebelumnya: Grady Booch OOD(ObjectOriented Design), Jim Rumbaugh OMT(Object Modeling Technique), dan Ivar Jacobson OOSE (Object-Oriented Software Engineering) [12].UML memiliki sembilan digram yang berbeda, namun diagram yang digunakan pada perancangan sistem informasi ini hanya empat, yaitu:

1) Use Case Diagram 
Diagram use case mendeskripsikan sebuah interaksi antara satu atau lebih aktor dengan sistem yang akan dibuat [12] seperti pada Tabel 5.

Tabel 5. Simbol Use Case Diagram(Sumber : [12])

\begin{tabular}{|c|c|c|}
\hline SIMBOL & NAMA & KETERANGAN \\
\hline & Actor & $\begin{array}{l}\text { Menspesifikasikan himpunan peran yang user mainkan } \\
\text { ketika berinteraksi dengan usecase }\end{array}$ \\
\hline & Dependency & $\begin{array}{l}\text { Hubungan dimana perubahan yang terjadi pada suatu } \\
\text { elemen mandiri (independent) akan mempengaruhi } \\
\text { elemen yang bergantung padanya elemen yang tidak } \\
\text { mandiri }\end{array}$ \\
\hline & Generalization & $\begin{array}{l}\text { Hubungan dimana objek anak (descendent) berbagi } \\
\text { perilaku dan struktur data dri objek yang ada diatasnya } \\
\text { objek induk (ancestor) }\end{array}$ \\
\hline & Include & $\begin{array}{l}\text { Menspesifikasikan bahwa usecase sumber secara } \\
\text { eksplisit }\end{array}$ \\
\hline & Extend & $\begin{array}{l}\text { Menspesifikasikan bahwa usecase target memperluas } \\
\text { perilaku dari usecase sumber pda suatu titik yang } \\
\text { diberikan }\end{array}$ \\
\hline & Association & $\begin{array}{l}\text { Apa yang menghubungkan antara objek satu dengan } \\
\text { objek yang lainnya }\end{array}$ \\
\hline & System & $\begin{array}{l}\text { Menspesifikasikan paket yang menampilkan sistem } \\
\text { secara terbatas }\end{array}$ \\
\hline & Usecase & $\begin{array}{l}\text { Deskripsi dari urutan aksi-aksi yang ditampilkan sistem } \\
\text { yang menghasilkan suatu hasil yang terstruktur bagi } \\
\text { suatu aktor }\end{array}$ \\
\hline & Collaboration & $\begin{array}{l}\text { Interaksi aturan-aturan dan elemen lain yang bekerja } \\
\text { sama untuk menyediakan perilaku yang lebih besar dari } \\
\text { jumlah dan elemen-elemennya }\end{array}$ \\
\hline & Note & $\begin{array}{l}\text { Elemen fisik yang eksis saat aplikasi dijalankan dan } \\
\text { mencerminkan suatu sumber daya komputasi. }\end{array}$ \\
\hline
\end{tabular}

\section{2) Activity Diagram}

Activity Diagram menggambarkan berbagai alir aktivitas dalam sistem yang sedang dirancang, bagaimana masing-masing alir berawal, decision yang mungkin terjadi, dan bagaimana mereka berakhir [12] seperti pada Tabel 6 .

Tabel 6. Simbol Activity Diagram(Sumber : [12])

\section{\begin{tabular}{|l|l|l|l|}
\hline NO & SIMBOL & NAMA & KETERANGAN \\
\hline
\end{tabular}}




\begin{tabular}{|l|l|l|l|}
\hline 1 & & Activity & $\begin{array}{l}\text { Memperlihatkan bagaimana masing-masing kelas } \\
\text { antarmuka saling berinteraksi satu sama lain }\end{array}$ \\
\hline 2 & & Action & $\begin{array}{l}\text { State dari sistem yang mencerminkan eksekusi dari } \\
\text { suatu aksi. }\end{array}$ \\
\hline 3 & $\bigcirc$ & $\begin{array}{l}\text { Initial } \\
\text { node }\end{array}$ & Bagaimana objek dibentuk atau diawali \\
\hline 4 & $\bigcirc$ & $\begin{array}{l}\text { Activity } \\
\text { final node }\end{array}$ & Bagaimana objek diakhiri \\
\hline 5 & $\vdots$ & Decision & $\begin{array}{l}\text { Dignakan untuk menggambarakn suatu keputusan/ } \\
\text { tindakan yang harus diambil pada kondisi tertentu }\end{array}$ \\
\hline 6 & $\downarrow$ & $\begin{array}{l}\text { Line } \\
\text { connector }\end{array}$ & $\begin{array}{l}\text { Digunakan untuk menghubungkan satu symbol dengan } \\
\text { simpol lainnya }\end{array}$ \\
\hline
\end{tabular}

3) Class Diagram

Class Diagram atau diagram kelas menggambarkan struktur sistem dari segi pendefinisian kelas-kelas yang akan dibuat untuk membangun sistem. Kelas memiliki apa yang disebut atribut dan metode atau operasi [12] seperti pada Tabel 7. 
Tabel 7. Simbol Class Diagram(Sumber : [12])

\begin{tabular}{|c|c|c|l|}
\hline NO & SIMBOL & NAMA & \multicolumn{1}{c|}{ KETERANGAN } \\
\hline 1 & & Class & $\begin{array}{l}\text { Himpunan dari objek-objek yang berbagi atribut serta } \\
\text { operasi yang sama }\end{array}$ \\
\hline 2 & - & Association & $\begin{array}{l}\text { Apa yang menghubungkan antara objek satu dengan } \\
\text { objek lainnya }\end{array}$ \\
\hline
\end{tabular}

\section{4) Sequence Diagram}

Sequence Diagram atau diagram sequence menggambarkan kelakuan atau perilaku objek pada use case dengan mendeskripsikan waktu hidup objek dan message yang dikirimkan dan diterima antar objek [12] seperti pada Tabel 8.

Tabel 8. Simbol Sequence Diagram(Sumber : [12])

\begin{tabular}{|c|c|c|l|}
\hline NO & SIMBOL & NAMA & \multicolumn{1}{c|}{ KETERANGAN } \\
\hline 1 & $\vdots$ & Life line & Objek entitas, antarmuka yang saling berinteraksi \\
\hline 2 & Actor & Digunakan untuk menggambarkan user/pengguna \\
\hline 3 & $\stackrel{\text { message }()}{\longrightarrow}$ & Message & $\begin{array}{l}\text { Spesifikasi dari komunikasi antar objek yang memuat } \\
\text { informasi-informasi tentang aktifitas yang terjadi }\end{array}$ \\
\hline 4 & - & Boundary & Digunakan untuk menggambarkan sebuah form \\
\hline 5 & $\bigcirc$ & $\begin{array}{c}\text { Control } \\
\text { class }\end{array}$ & Digunakan untuk menghubungkan boundary table \\
\hline 6 & $\bigcirc$ & $\begin{array}{c}\text { Entity } \\
\text { class }\end{array}$ & $\begin{array}{l}\text { Digunakan untuk menggambarkan hubungan kegiatan } \\
\text { yang akan dilakukan. }\end{array}$ \\
\hline
\end{tabular}

Flowchart adalah bagan-bagan yang mempunyai arus yang menggambarkan langkahlangkah penyelesaian suatu masalah [13]. Flowchart disusun atau alur, yang digunakan untuk menghubungkan antara simbol yang satu dengan yang lain seperti pada Tabel 9.

Tabel 9. Simbol Flowchart (Sumber : [13])

\begin{tabular}{|c|c|c|}
\hline SIMBOL & NAMA & KETERANGAN \\
\hline & Proses & Menunjukkan kegiatan proses dari operasi \\
\hline & Manual input & Menunjukkan input yang dilakukan dengan \\
\hline & Keputusan & Penyeleksian kondisi di dalam program. \\
\hline & Input/Output & $\begin{array}{l}\text { Menyatakan proses input dan output tanpa } \\
\text { tergantung dengan jenis peralatannya. }\end{array}$ \\
\hline
\end{tabular}




\begin{tabular}{|c|cl|}
\hline $1+$ & Garis alir & Menunjukkan arus dari proses. \\
\hline$\square$ & Terminal & Menunjukkan awal dan akhir dari suatu \\
\hline$\square$ & Manual & Menyatakan suatu tindakan yang tidak \\
\hline$\square$ & Disk Storage & $\begin{array}{l}\text { Menyatakan input berasal dari disk atau } \\
\text { outnut disimnan ke disk. }\end{array}$ \\
\hline$\square$ & Document & Mencetak laporan ke printer. \\
\hline
\end{tabular}

Kuesioner model skala likert yaitu yang terdiri atas pernyataan-pernyataan positif dan negatif. Untuk setiap pertanyaan disediakan lima pilihan jawaban, yaitu sangat setuju (SS), setuju (S), ragu-ragu (RR), tidak setuju (TS), sangat tidak setuju (STS). (Pilihan jawaban netral $(\mathrm{N})$ tidak digunakan, hal ini dilakukan untuk mendorong responden melakukan pilihan jawaban dan menghindari jawaban aman [14].Untuk keperluan analisis kuantitatif, maka jawaban dari pernyataan diberi skor seperti pada Tabel 10.

Tabel 10. Skor Jawaban Responden (Sumber : [14])

\begin{tabular}{|c|c|}
\hline Jawaban & Skor \\
\hline Sangat Setuju (ST) & 5 \\
\hline Setuju (S) & 4 \\
\hline Ragu-Ragu (RR) & 3 \\
\hline Tidak Setuju (TS) & 2 \\
\hline Sangat Tidak Setuju (STS) & 1 \\
\hline
\end{tabular}

Untuk mencari nilai persentase dari masing-masing jawaban kuesioner digunakan rumus skala likert [14] seperti pada rumus dibawah ini.

$P=\frac{S}{\text { skor ideal }} \times 100 \%$

Sedangkan untuk menghitung persentase kuesioner secara keseluruhan digunakan[14] seperti pada rumus dibawah ini.

$P K=\frac{\text { Epersentase pernyataan sampel }}{\text { Epersentase keseluruhan }}$

Keterangan rumus dapat dilihat pada Tabel 11.

Tabel 11. Keterangan Rumus Mencari Persentase Kuesioner(Sumber : [14])

\begin{tabular}{|l|l|}
\hline \multicolumn{1}{|c|}{ Nama } & \multicolumn{1}{c|}{ Keterangan } \\
\hline PK & Persentase Kuesioner \\
\hline $\mathrm{P}$ & Nilai persentase yang dicari \\
\hline $\mathrm{S}$ & Jumlah frekuensi dikalikan dengan skor yang ditetapkan \\
\hline Skor ideal & Nilai tertinggi dikalikan dengan jumlah sampel \\
\hline Nilai Tertinggi & 5 \\
\hline
\end{tabular}


Vuforia SDK merupakan software untuk augmented reality, yang menggunakan sumber yang konsisten mengenai computer vision yang fokus pada image recognition. Dengan support untuk iOS, Android, dan Unity3D,platform Vuforia mendukung para pengembang untuk membuat aplikasi yang dapat digunakan di hampir seluruh jenis smartphone dan tablet. Pengembang juga diberikan kebebasan untuk mendesain dan membuat aplikasi yang mempunyai kemampuan antara lain teknologi computer vision tingkat tinggi yang mengijinkan developer untuk membuat efek khusus pada mobile device, tracking dan Detection tingkat lanjut, dan solusi pengaturan database gambar yang fleksibel[15].

Image tracking atau image target adalah metode pendeteksian dan pelacakan target berdasarkan gambar.Vuforia SDK mendeteksi dan melacak natural fitur yang ditemukan pada sebuah gambar dengan membandingkan pada gambar yang telah ditentukan di database. Setelah Image Target terdeteksi, maka Vuforia SDKakan melacak gambar asalkan terdapat bagian marker yang terlihat dikamera [15].

Peranan teknologi $A R$ dalam mendukung pembelajaran, salah satunya sudah dilakukan penelitian sebelumnya oleh peneliti lain dalam jurnalnya yang berjudul Pengenalan Hewan Augmented RealityBerbasis Android, yaitu bahwa hasil pengujian berdasarkan calon pengguna menunjukan bahwa aplikasi tersebut dapat memberikan pengenalan hewan yang menarik, menyenangkan dan layak digunakan untuk pengenalan hewan kepada anak usia TK. Persentase sangat layak sebesar 33,75\%, persentase layak sebesar $56,25 \%$, persentase cukup layak sebesar $10 \%$, dan persentase tidak layak sebesar $0 \%$ [16].Terdapat juga penelitian lain dalam jurnalnya berjudul Aplikasi Pembelajaran Berbasis Augmented Reality Pada Buku Panduan Wudhu Untuk Anak, yaitu bahwa Pengunaan media pembelajaran aplikasi berbasis $A R$ pada buku panduan wudhu terbukti mampu meningkatkan nilai rata-rata hasil belajar siswa, terbukti dengan hasil evaluasi pembelajaran wudhu di TK A mengalami peningkatan dari 62,99 menjadi 75,8, TK B mengalami peningkatan dari 58,2 menjadi 69, di TK C mengalami peningkatan dari 69,16 menjadi 83,4 [17].

\section{Analisis dan Perancangan}

\subsection{Analisis Kebutuhan Non-Fungsional}

Kebutuhan non-fungsional yaitu menjelaskan perangkat-perangkat apa saja yang mendukung dalam aplikasi. Terdapat perangkat keras dan perangkat lunak yang mendukung diantaranya.

\subsubsection{Analisis Perangkat Keras}

Analisis kebutuhan perangkat keras dalam membangun aplikasi yaitu. 
Tabel 12. Analisis Perangkat Keras

\begin{tabular}{|l|l|}
\hline \multicolumn{1}{|c|}{ Laptop } & \multicolumn{1}{|c|}{ Smartphone } \\
\hline a.ProcessorAMD Quad Core A8-7410 & a. Merk LENOVO model K4 Note (5.5”) \\
\hline b.Layar 14" (resolusi layar 1366 x 768) & $\begin{array}{l}\text { b.Processor Octa Core 1.5 Ghz Cortex- } \\
\text { A53 }\end{array}$ \\
\hline c.Memory RAM 4 GB & c. Memory 16 GB Internal 3 GB RAM \\
\hline $\begin{array}{l}\text { d.Mouse, Keyboard dan Speaker yang } \\
\text { standar }\end{array}$ & \multicolumn{1}{|c|}{. } \\
\hline
\end{tabular}

\subsubsection{Analisis Perangkat Lunak}

Analisis kebutuhan perangkat lunak dalam membangun aplikasi yaitu.

Tabel 13. Analisis Perangkat Lunak

\begin{tabular}{|l|l|}
\hline 1. Sistem OperasiMicrosoft Windows 10 & 4. Vuforia SDK 6.2.10 \\
$\begin{array}{l}\text { Pro (64-bit) } \\
\text { 2. Sistem Operasi Android versi 4.4.4 }\end{array}$ & $\begin{array}{l}\text { 6. Adonder 2.78.0 } \\
\text { Kitkat }\end{array}$ \\
$\begin{array}{l}\text { 3. Sound of Text } \\
\text { Game Engine Unity 3D 5.5.0f3 (32-bit) }\end{array}$ & \\
\hline
\end{tabular}

\subsubsection{Analisis Pengguna}

Sasaran untuk pengguna dari sistem aplikasi ini adalah para pengajar untuk anak usia 5 11 tahun yang belajar nama-nama buah dari huruf Hangeul (Bahasa Korea). Kebutuhan user yang dibutuhkan untuk menjalankan aplikasi ini yaitu Android versi minimal 4.1 Jelly Bean.

\subsection{Analisis Kebutuhan Fungsional}

Analisis kebutuhan ini akan dibuat sebuah pemodelan sistem yang digunakan dalam pemodelan object oriented dan flowmap metode yang digunakan untuk menggambarkan seluruh proses dan objek adalah UML(Unified Model Language) yang didalamnya mencakup use case diagram, activity diagram dan sequence diagram.

Diagram use case sistem yang diusulkan dapat dilihat pada Gambar 1. 


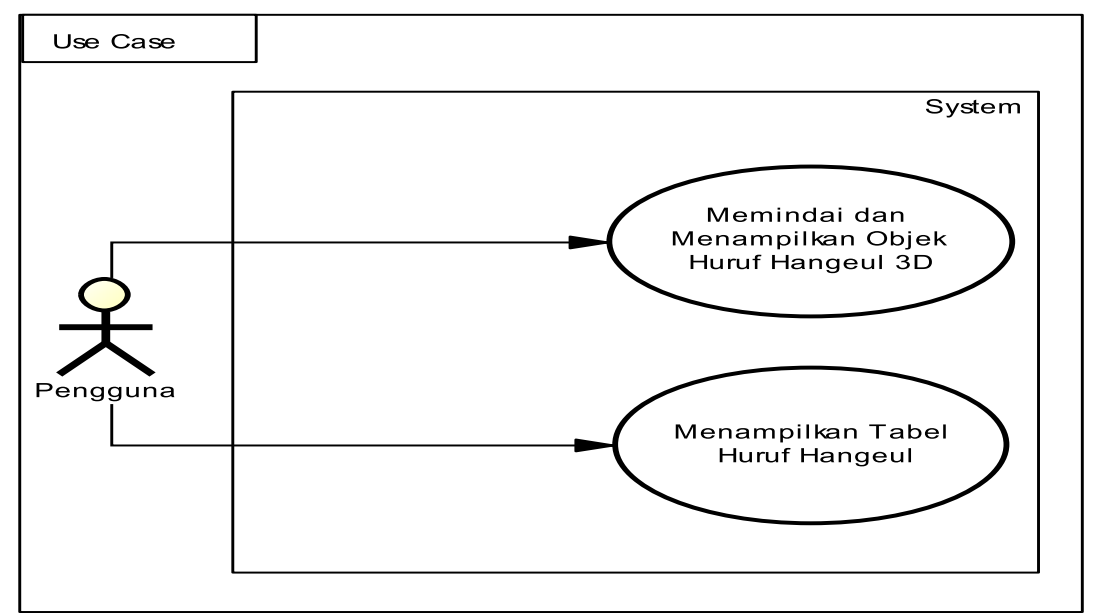

Gambar 1. Use Case Diagram

Deskripsi Use Case Menampilkan Objek Huruf Hangeul 3D.

Tabel 14. Use CaseMenampilkan Objek Huruf Hangeul 3D

\begin{tabular}{|c|c|}
\hline \multirow{3}{*}{$\begin{array}{l}\text { Nama use case } \\
\text { Nomor } \\
\text { Tujuan } \\
\text { Kondisi Awal }\end{array}$} & \multirow[b]{2}{*}{$\begin{array}{l}\text { : Menampilkan Objek Huruf Hangeul 3D } \\
: \text { AR.HB-P01 } \\
: \text { Menampilkan objek huruf Hangeul 3D } \\
: \text { Sistem menampilkan objek huruf Hangeul } \\
\text { 3D sesuai marker yang telah dipilih } \\
\text { : Pengguna }\end{array}$} \\
\hline & \\
\hline & \\
\hline \multicolumn{2}{|c|}{$\begin{array}{l}\text { I. Marker Good } \\
\text { Keterangan : marker yang saat terdaftar di vuforia mendapat rating tinggi dan objek } \\
\text { langsung muncul saat marker di scan. }\end{array}$} \\
\hline Reaksi Actor & Reaksi Sistem \\
\hline \multicolumn{2}{|l|}{ 1. MemilihmenuNama Buah } \\
\hline & 2. Kamera terbuka \\
\hline \multicolumn{2}{|l|}{$\begin{array}{l}\text { 3. Scan pada marker yang sudah } \\
\text { disediakan }\end{array}$} \\
\hline & $\begin{array}{l}\text { 4. Deteksi marker dan menampilkan objek } \\
\text { huruf Hangeul 3D }\end{array}$ \\
\hline \multicolumn{2}{|l|}{ 5. Pilih tombol suara } \\
\hline & $\begin{array}{l}\text { 6. Mengeluarkan suara yang membantu } \\
\text { cara membaca huruf Hangeul yang } \\
\text { muncul setelah scanmarker }\end{array}$ \\
\hline
\end{tabular}


Kondisi akhir : Sistem menampilkan objek huruf Hangeul 3D dan tombol yang dapat mengeluarkan suara.

\section{Marker Bad}

\section{Kondisi Alternatif}

Keterangan : marker yang saat terdaftar di vuforia mendapat rating rendah dan objek tidak langsung muncul saat marker di scan.

\begin{tabular}{|l|l|}
\hline & $\begin{array}{c}\text { 4. Menunggu lebih lama saat deteksi } \\
\text { kamera, hingga objek huruf Hangeul } \\
\text { 3D muncul }\end{array}$ \\
\hline Kondisi akhir : Sistem menampilkan objek huruf Hangeul 3D sedikit lebih lama. \\
\hline
\end{tabular}

Deskripsi Use Case Menampilkan Tabel Huruf Hangeul

Tabel 15. Use Case Menampilkan Tabel Huruf Hangeul

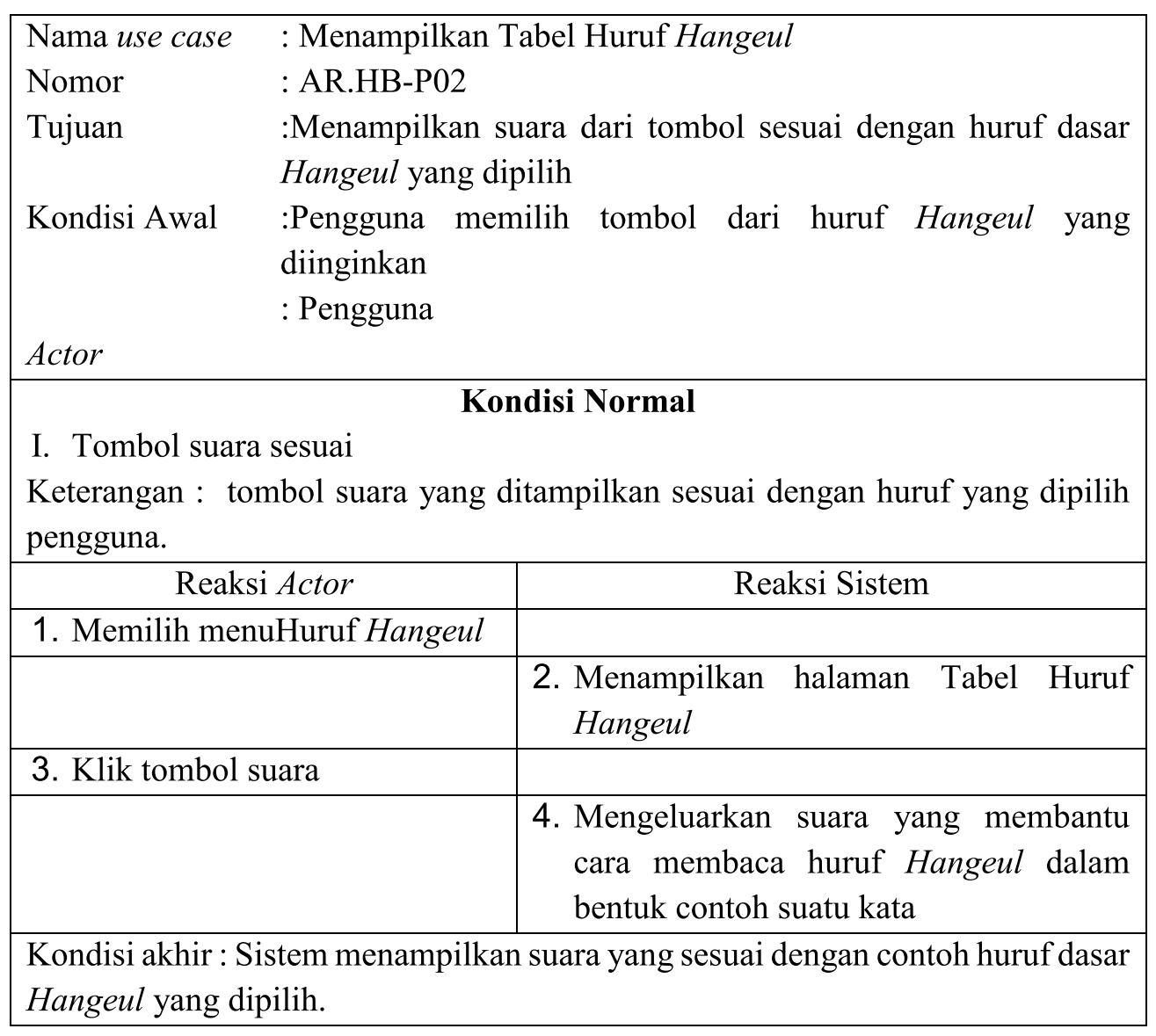




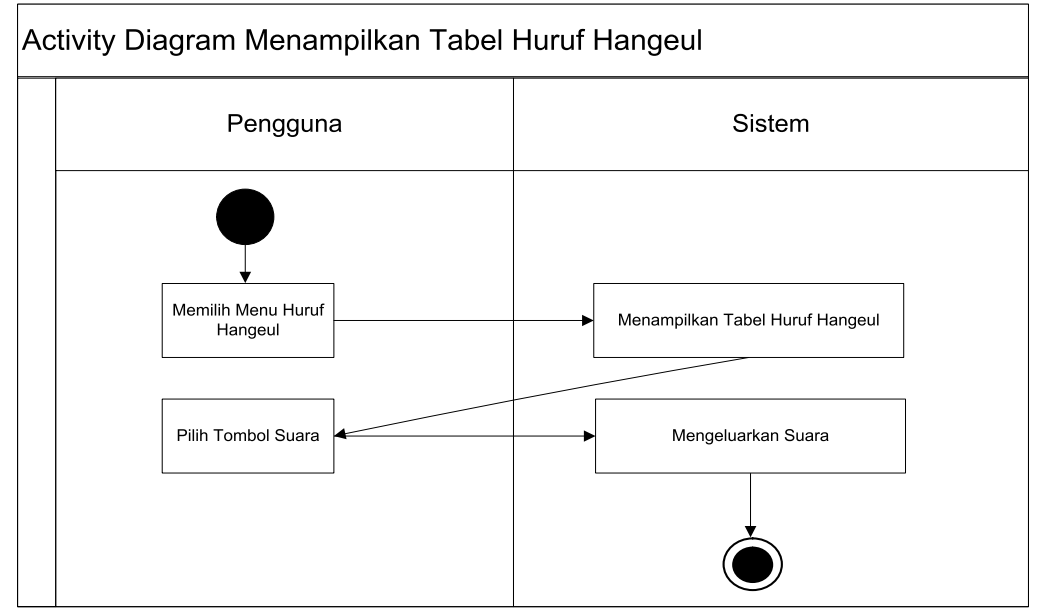

Gambar 2. Activity Diagram Menampilkan Tabel Huruf Hangeul

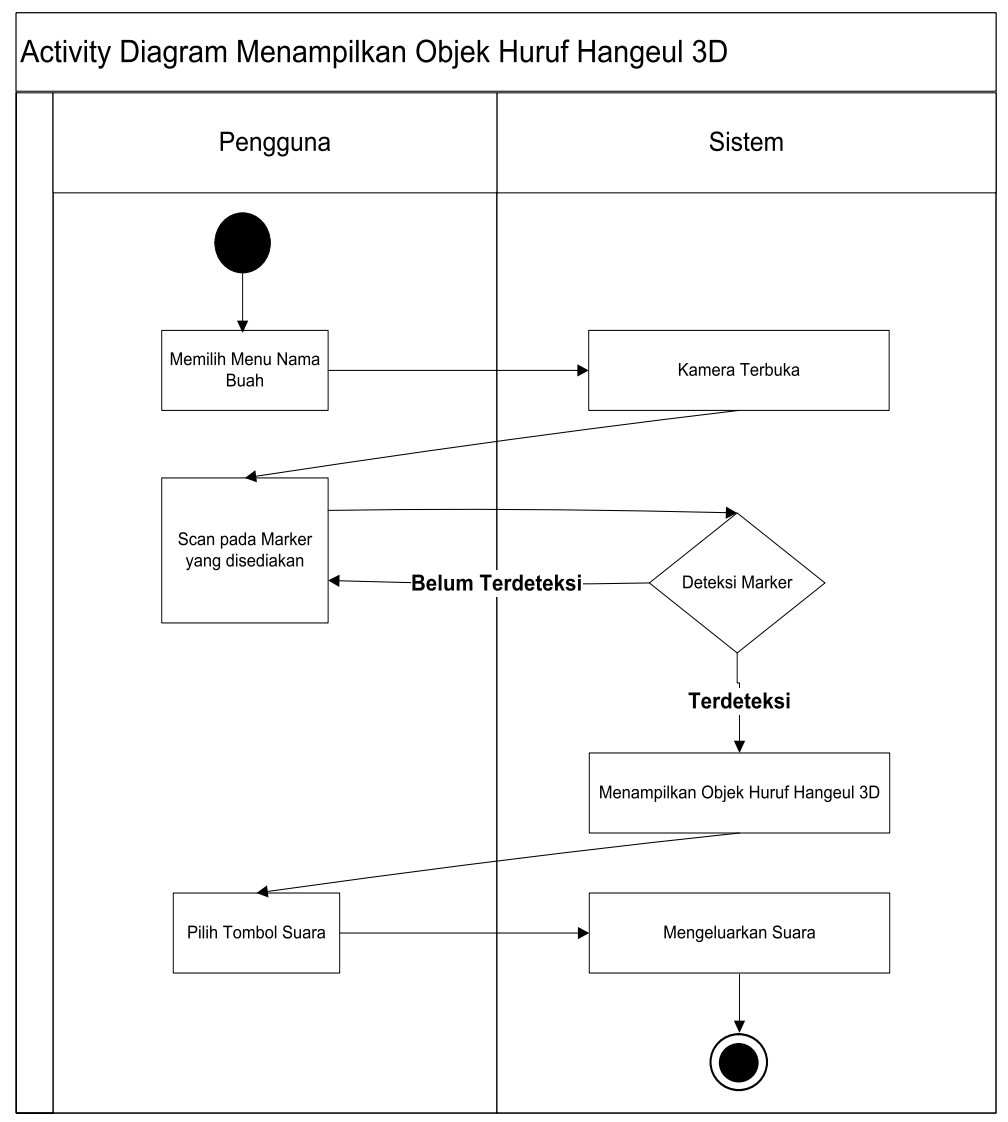

Gambar 3. Activity Diagram Menampilkan Objek Huruf Hangeul 3D 


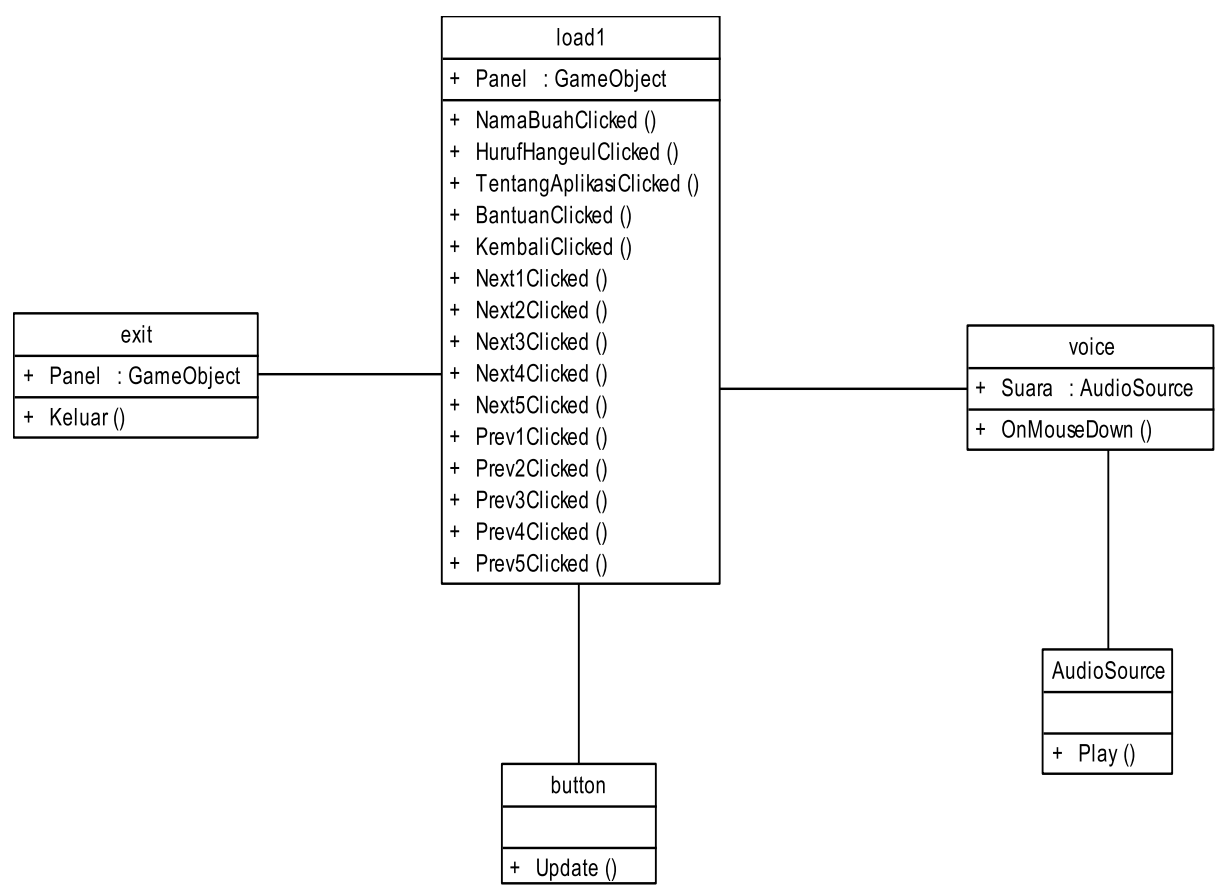

Gambar 4. Class Diagram

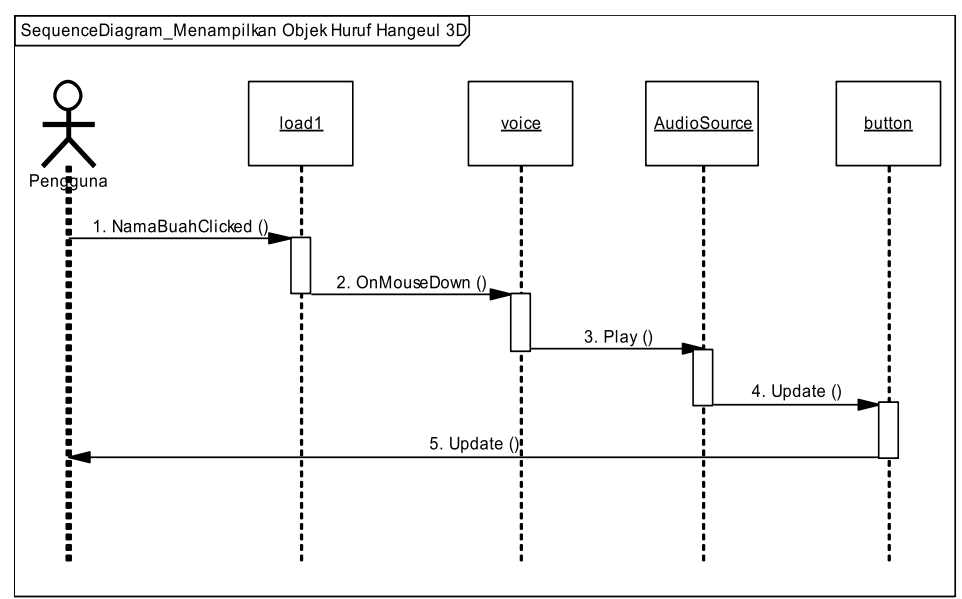

Gambar 5. Sequence Diagram Menampilkan Objek Huruf Hangeul 3D

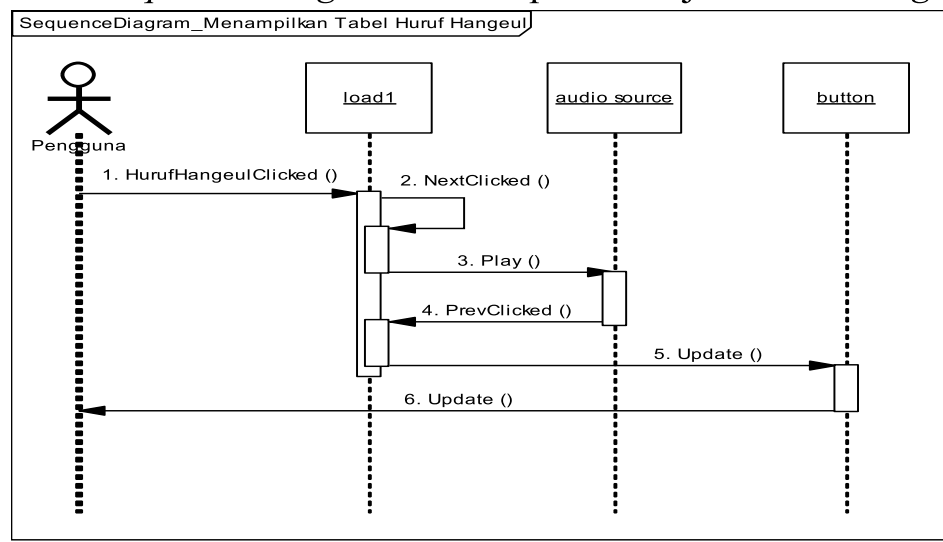


Gambar 6. Sequence Diagram Menampilkan Tabel Huruf Hangeul

\subsection{Implementasi Antarmuka}

Tampilan pada aplikasi pengenalan macam-macam buah dari huruf Hangeul (Bahasa Korea) menggunakan teknologi Augmented Reality berbasis Android dapat dilihat dibawah ini:

a. Tampilan Icon Aplikasi

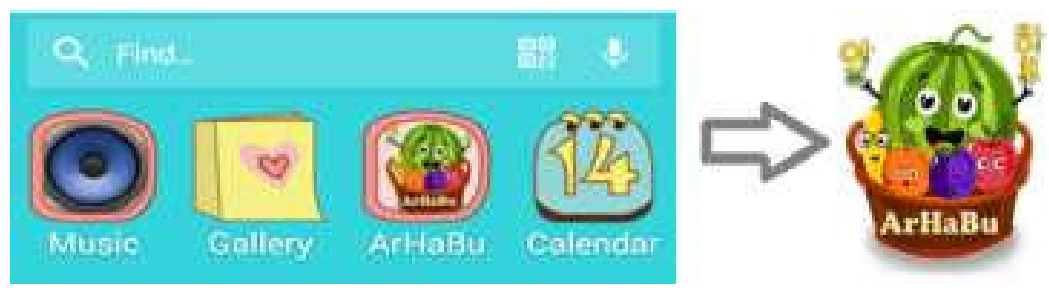

Gambar 7. Tampilan Icon Aplikasi

b. Tampilan Menu Utama

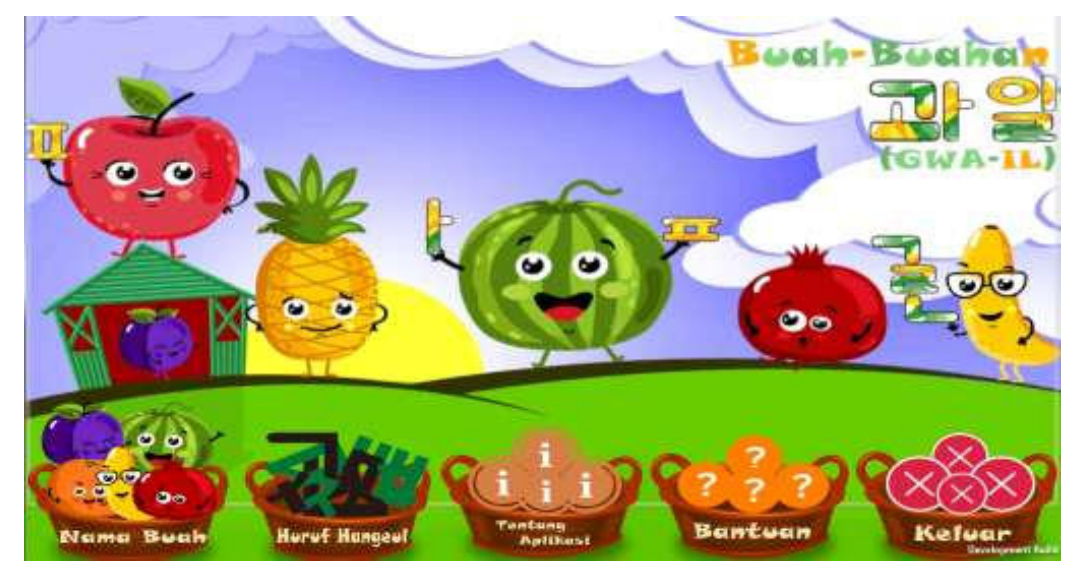

Gambar 8. Tampilan Menu Utama

c. Tampilan Menu Nama Buah 


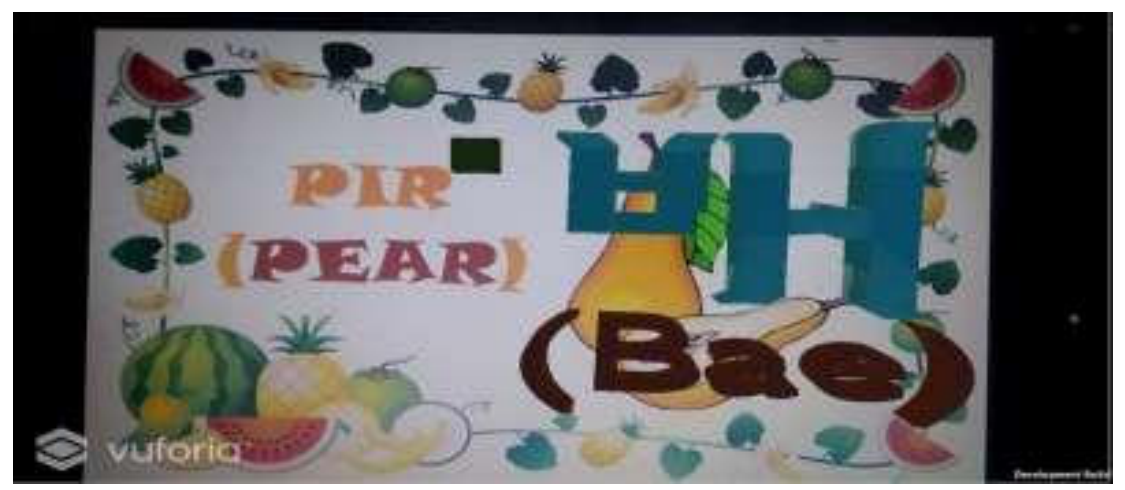

Gambar 9. Tampilan Menu Nama Buah

d. Tampilan Halaman Menu Huruf Hangeul

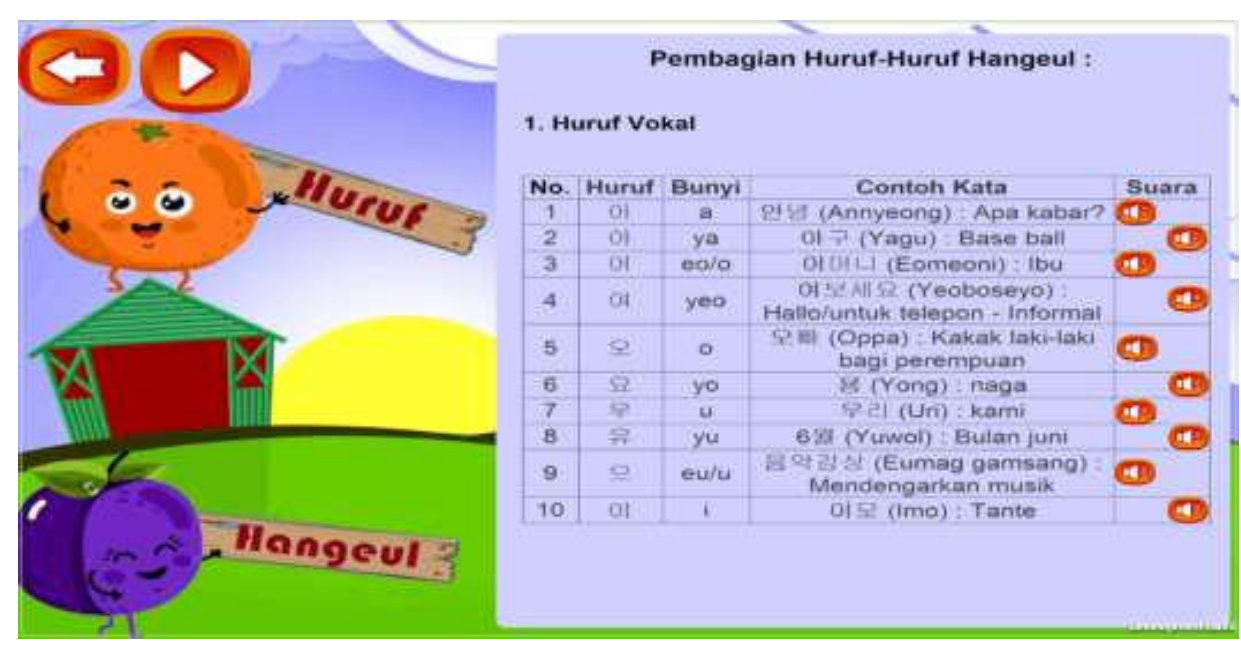

Gambar 10. Tampilan Huruf Hangeul Halaman Awal

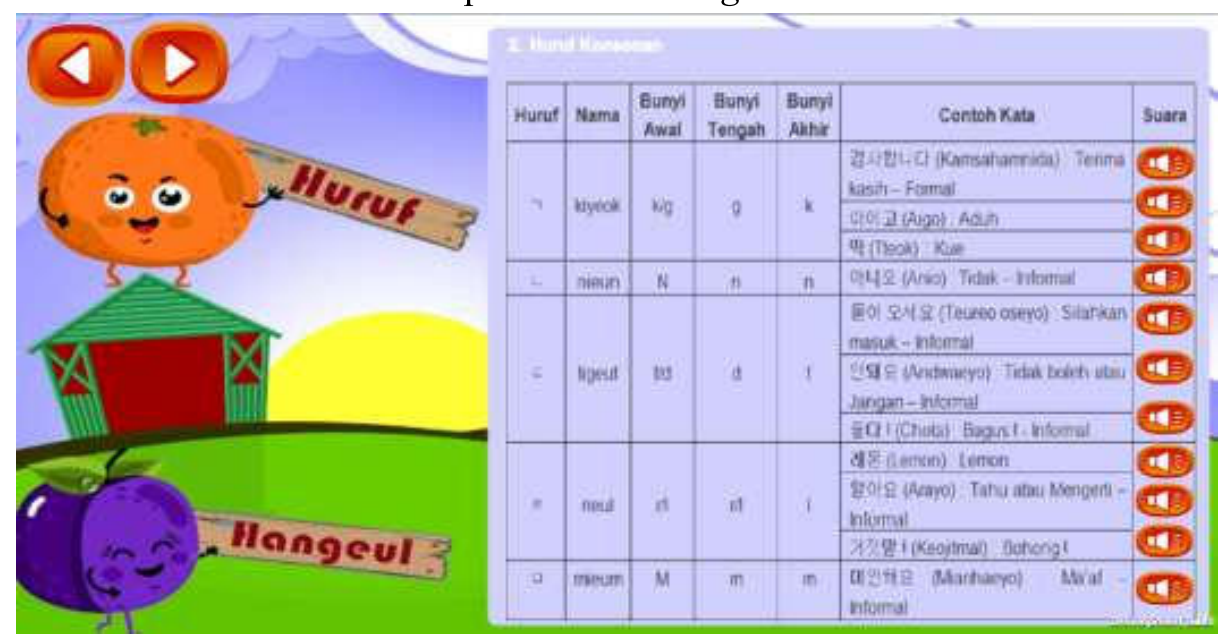

Gambar 11. Tampilan Huruf Hangeul Halaman Tengah 


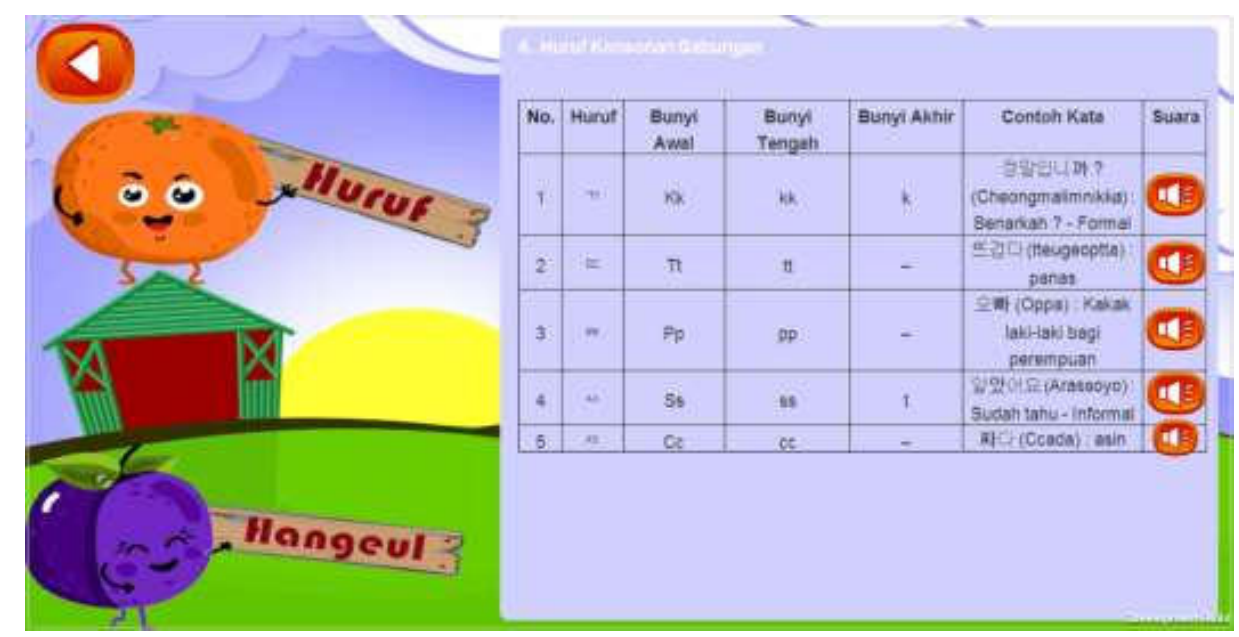

Gambar 12. Tampilan Huruf Hangeul Halaman Akhir

e. Tampilan Halaman Menu Tentang Aplikasi

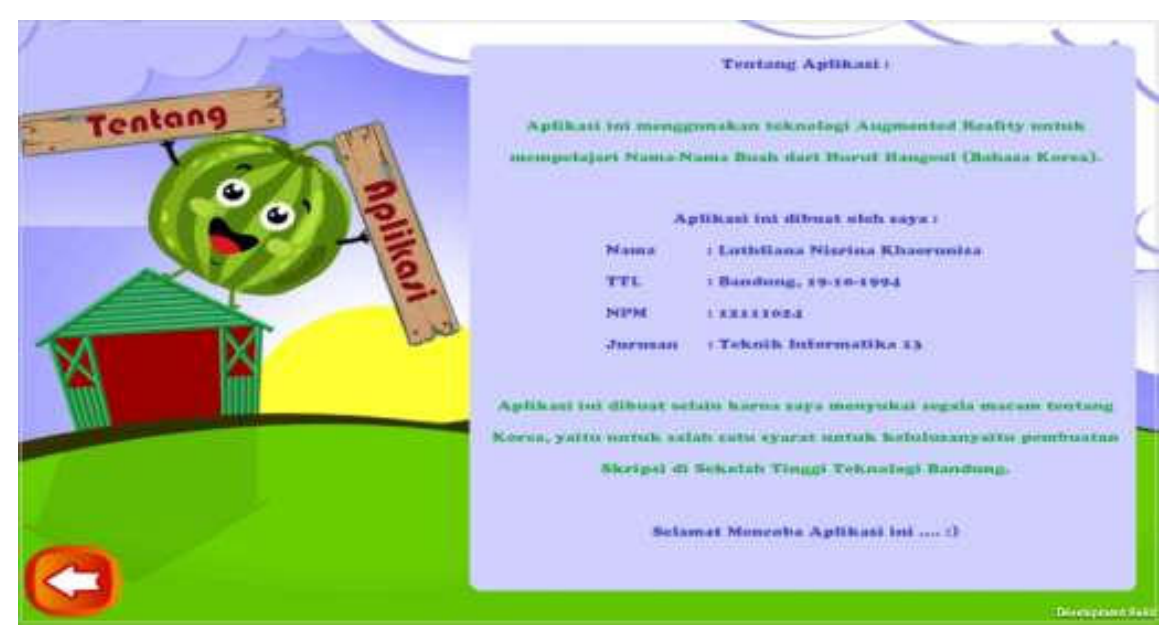

Gambar 13. Tampilan Halaman Menu Tentang Aplikasi

\subsection{Metode Pengujian}

Dalam pengujian ini menggunakan metode kuesioner, kuesioner yang dipilih adalah model skala likert. Berdasarkan kesimpulan hasil pengumpulan data kuesioner dapat dilakukan perhitungan persentase untuk setiap pernyataan yang diberikan, adapun penjabarannya sebagai berikut.

a. Secara umum aplikasi ini dapat memberikan informasi tentang Macam-Macam Buah dari Huruf Hangeul.

Tabel 16. Perhitungan Persentase Pernyataan Ke-1

\begin{tabular}{|l|c|c|c|}
\hline Keterangan & Skor & Responden & Jumlah Skor \\
\hline SS & 5 & 3 & 15 \\
\hline S & 4 & 3 & 12 \\
\hline
\end{tabular}




\begin{tabular}{|l|c|c|c|}
\hline RR & 3 & - & - \\
\hline TS & 2 & - & - \\
\hline STS & 1 & - & - \\
\hline Jumlah & & $\mathbf{6}$ & $\mathbf{2 7}$ \\
\hline
\end{tabular}

Maka diperoleh data sebagai berikut:

$$
P=\frac{27}{30} \times 100 \%=90 \%
$$

Berdasarkan nilai persentase tersebut, maka dapat disimpulkan bahwa penilaian terhadap aplikasi Pengenalan Macam-Macam Buah dari Huruf Hangeul (Bahasa Korea) menggunakan Teknologi Augmented Reality berbasis Android adalah 90\% dengan responden 6 pengajar dari yang diharapkan $100 \%$.

Dengan menggunakan rumus persentase keseluruhan maka didapatkan perhitungan sebagai berikut.

$\mathrm{PK}=(90 \%+90 \%+86,6666 \%+93,3333 \%+86,6666 \%+96,6666 \%+93,3333 \%+100 \%$

$+86,6666 \%+93,3333 \%) / 1000 \%$

$\mathrm{PK}=916,6663 \% / 1000 \%=91,66663 \%$

\subsection{Hasil Pengujian}

Berdasarkan hasil pengujian yang telah dilakukan dengan responden pengajar, menunjukan bahwa aplikasi yang dibangun ini sudah memiliki tampilan yang cukup menarik dan juga aplikasi yang dibangun mudah digunakan oleh para responden yang menilai. Selain itu aplikasi yang dibangun juga cukup memberikan informasi tentang macam-macam buah dari huruf Hangeul. Bagi para responden juga aplikasi ini dapat membantu dalam proses belajar mengajar karena siswa/i yang antusias dan lebih aktif saat belajar.

\section{Kesimpulan dan Saran}

\subsection{Kesimpulan}

Berdasarkan hasil analisis dan pengujian padapenelitian Pengenalan Macam-Macam Buah dari Huruf Hangeul Menggunakan Teknologi Augmented Reality Berbasis Android, maka dapatdiambilkesimpulan sebagai berikut.

a. Dengan adanya perancangan dan pembuatan aplikasi pengenalan nama-nama buah dari huruf Hangeul (Bahasa Korea) menggunakan teknologi terbaru yaitu Augmented Reality berbasis Android membuat para pengajar lebih mudah dalam memperkenalkan materi kepada siswa/i.

b. Fitur yang ada dalam aplikasi ini antara lain menampilkan objek huruf Hangeul 3D, suara bacaan dari kata tersebut juga terdapat menu untuk mempelajari dasar-dasar huruf Hangeul disertai tombol suara untuk membantu dalam membaca kata yang benar. Hasil pengujian berdasarkan calon pengguna menunjukan bahwa aplikasi ini 
dapat memberikan pengenalan macam-macam buah yang cukup menarik dan mudah digunakan untuk siswa/i di tempat les kelas dasar.

\subsection{Saran}

Dalam pengembangan aplikasi pengenalan macam-macam buah dari huruf Hangeul menggunakan teknologi Augmented Reality berbasis Android masih banyak terdapat kekurangan, makadari ituperlu banyak pembenahan yang harusdilakukan pada penelitian selanjutnya. Beberapa halyang disarankan yaitu.

a. Aplikasi dapat berjalan secara online, agar marker dapat diunduh secara langsung.

b. Menambah jumlah buah dan membuat marker menjadi lebih menarik.

c. Metode Marker dapat diganti menjadi metode markerless.

d. Penambahan pada desain dan animasi objek agar lebih baik lagi.

\section{Daftar Pustaka}

[1] Lestari, Mustiana. Vocabulary for Daily ConversationBahasa Korea. Jakarta: Kawah Media. 2013.

[2] Arifin, Tedy. Jurnal Teknik Informatika. Aplikasi Pengenalan Huruf Hangeul Berbasis Multimedia Interaktif. 2013; 1(1): 349.

[3] Balqis, Zahrani, S.S. Bahasa Korea Super Mudah. Yogyakarta: Familia Publisher. 2012.

[4] Yoga Aprillion Saputra. Jurnal Ilmiah Komputer dan Informatika. Implementasi Augmented Reality (Ar) Pada Fosil Purbakala Di Museum Geologi Bandung. 2014; 1(1): 3 .

[5] Ardianto Wahyu, Anggraeni Wiwik, Mukhlason Ahmad. Jurnal Informatika. Pembuatan Sistem Pakar Untuk Pendeteksian dan Penanganan Dini Pada Sapi Berbasis Mobile Android Dengan Kajian Kinerja Teknik Knowledge Representation. 2012; 3.

[6] Safaat. Pemrograman Aplikasi Mobile Smarthpone dan Tablet PC Berbasis Android. Bandung: Informatika. 2012.

[7] Muharom Arzan, Cahyana Rinda M.T, Bunyamin H M.Kom. Pengembangan Aplikasi Sunda Berbasis Android Menggunakan Metode Rapid Application Development (RAD). Sekolah Tinggi Teknologi Garut. Garut. 2013.

[8] Yudistira. Jurnal Telematika. Mobile Game Edukasi Aritmatika dan Geometri. 2014; $7: 78-79$.

[9] Evi S, Hernando I.T., Theofilus F.H, Willy. Rancang Bangun Edugame Pembelajaran Kesehatan Gigi Untuk Anak-anak Berbasis Unity 3D. 2015.

[10] Yeti Ekasari. Merancang Game Petualangan "Binggo" Menggunakan Unity 3D Game Engine. Sekolah Tinggi Manajemen Informatika dan Komputer (AMIKOM). 2012.

[11] Nakov, Svetlin et al., 2013, Fundamentals of Computer ProgrammingwithC\#. 
Diakses Online pada tanggal 15 Maret 2017. http://www.introprogramming.info/wpcontent/uploads/2013/07/Books/CSharpEn/Fundamentals-of-Computer-

Programming-with-CSharp-Nakov-eBook-v2013.pdf.

[12] Sugiarti, Yuni, S.T.M.Kom. Analisis dan Perancangan UML (Unified Modeling Language) Generated VB.6. Yogyakarta: Graha Ilmu. 2013.

[13] Prasetio, Adhi. Buku Pintar Pemrograman Web. Jakarta: Mediakita. 2012.

[14] Sugiyono. Metode Penelitian Pendidikan (Pendekatan Kuantitatif, Kualitatif dan $R \& D)$. Bandung: Alfabeta. 2012.

[15] Eka Iswandy. Jurnal Teknologi Informatika. Sistem Penunjang Keputusan Untuk Menentukan Penerimaan Dana Santunan Sosial Anak Nagari Dan Penyalurannya Bagi Mahasiswa Dan Pelajar Kurang Mampu Di Kenagarian Barung - Barung Balantai Timur. 2015; 3(2): 73.

[16] Prima Rosyad. Pengenalan Hewan Augmented Reality Berbasis Android.(Universitas Muhammadiyah Surakarta. Surakarta). 2014; 8.

[17] Nur Jazilah. Aplikasi Pembelajaran Berbasis Augmented Reality Pada Buku Panduan Wudhu Untuk Anak. (Universitas Islam Negeri Maulana Malik Ibrahim. Mala 